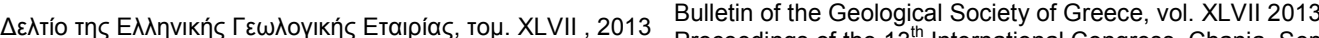
Proceedings of the $13^{\text {th }}$ International Congress, Chania, Sept.

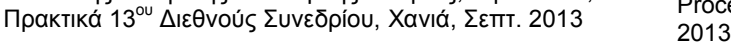

\title{
RECENT COASTLINE CHANGES OF FAN-DELTAS IN THE WESTERN GULF OF CORINTH, CENTRAL GREECE
}

\author{
Perrou Th. ${ }^{1}$, Kaza I. ${ }^{1}$, Efthymiadis V. ${ }^{1}$, Karymbalis E. ${ }^{1}$ and Chalkias C. ${ }^{1}$ \\ ${ }^{1}$ Department of Geography, Harokopio University of Athens, 70 El. Venizelou Str., 17671 Athens, \\ Greece,dperrou@central.ntua.gr,Ioanna.Kaza.1988@gmail.com,bilefth@hotmail.com. \\ karymbalis@hua.gr,xalkias@hua.gr
}

\begin{abstract}
This study deals with the assessment of recent shoreline change rates along the fandeltas of Finix, Tholopotamo, Lagadi, Meganitas, Selinous, Kerinitis, and Vouraikos streams by using GIS and Remote Sensing techniques. These Late Holocene fandeltas have been formed by high gradient braided streams that deposit their coarse sediment load along the southern coast (North Peloponnese) of the western Gulf of Corinth. For the purposes of the study a spatial database was constructed, organized and implemented consisting of analogue detailed (at the scale of 1:5000) topographic diagrams, and orthorectified aerial photos taken in 1945, 1996 and 2008. Comparisons of fan-deltas shoreline positions for the periods 1945 vs. 1996 and 1945 vs. 2008 were made and the segments of the coastline along the aprons of the fan-deltas which are subject to erosion accretion were defined. Coastal erosion is the main dominant geomorphic process along a significant part of the fan deltas coastline. The highest retreat rate value (2.44 m/yr for the period 1945-1996) was estimated for the Finix stream fan delta, about $150 \mathrm{~m}$ west of the river mouth, while the highest accretion rates since 1945 (3.10 and $3.00 \mathrm{~m} / \mathrm{yr}$ ) occurred at the mouths of Vouraikos and Selinous rivers respectively.
\end{abstract}

Key words: Geographic Information System (GIS), shoreline change rates, fandeltas, Gulf of Corinth, Greece.

\section{Пєрі́ $\eta \psi \eta$}

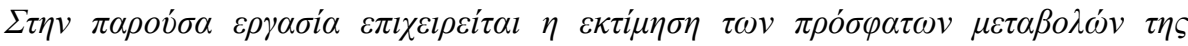

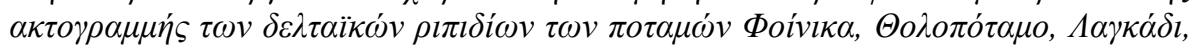

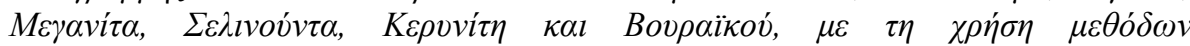

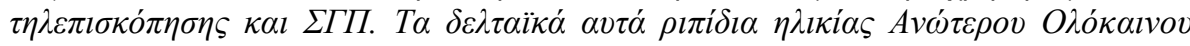

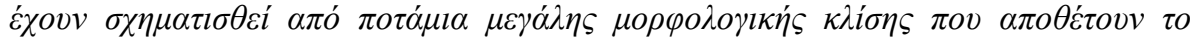

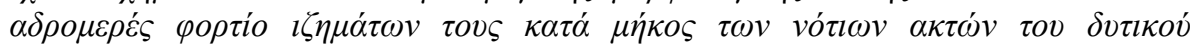

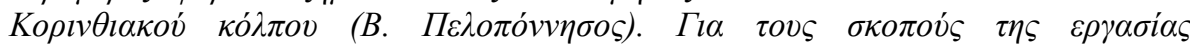

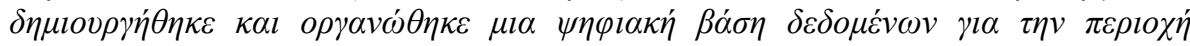

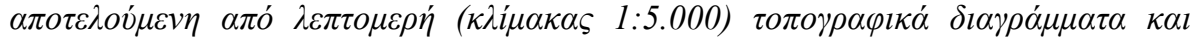

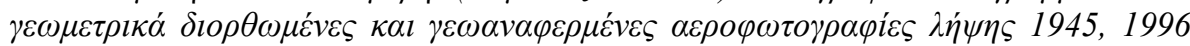

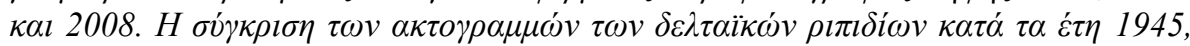

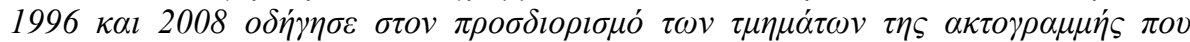

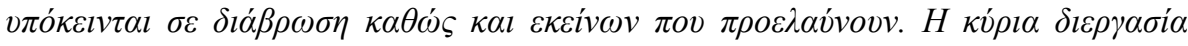

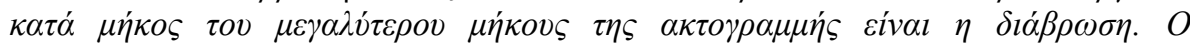




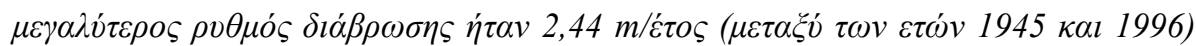

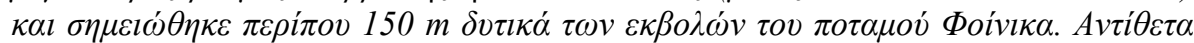

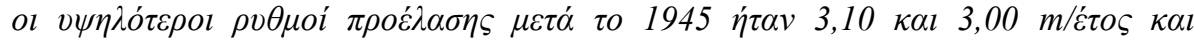

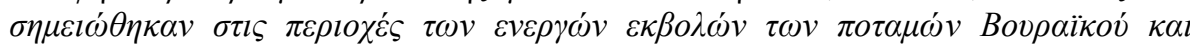
$\sum \varepsilon \lambda \iota v o v ́ v \tau \alpha \alpha v \tau i \sigma \tau o l \chi \alpha$.

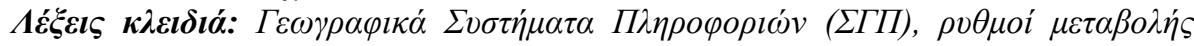

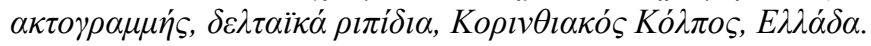

\section{Introduction}

Coastal monitoring and research-informed decision-making have a crucial role in assisting local authorities to develop their shoreline management plans. Quantitative assessment of recent shoreline change rates is a part of the coastal monitoring that helps significantly in long-term predictions of shoreline positions (Esteves et al., 2009). Such predictions are a useful tool for coastal managers who need to propose future shoreline management and development strategies.

In Greece the most distinctive coastline changes concern beach zones of low lying coastal plains (mainly river deltas) and are associated with the progradation of active river mouths or the retreat of abandoned channels (Maroukian \& Karymbalis, 2004). Extremely high mean erosion rates up to more than $20 \mathrm{~m} / \mathrm{yr}$ are very rare and characterize certain deltaic locations such as the Acheloos river delta. These extreme retreat rates are associated with human interference including dam constructions, stream flow diversion etc. Usually erosion rates in deltaic and low-lying coastal plains are less than $2 \mathrm{~m} / \mathrm{yr}$. By contrast, active river mouths appear to be areas of rapid accretion with progradation rates up to more than $4 \mathrm{~m} / \mathrm{yr}$ (Papadopoulos, 2009). In beaches that are not near large river deltas retreat rates range from 0.5 to $1 \mathrm{~m} / \mathrm{yr}$ (Foteinis et al., 2010).

This paper aims at assessing mean shoreline change rates along the fan deltas of Finix, Tholopotamos, Lagadi, Meganitas, Selinous, Kerinitis, and Vouraikos streams using remote sensing data and GIS techniques. The fan deltas of the study area are located along the southern coast of the western Gulf of Corinth and have been prograding in deep waters since the deceleration of Holocene sea-level rise.

\section{Study Area}

The study area shoreline lies on the southern coast of the Gulf of Corinth, extending for $31.4 \mathrm{~km}$, from the village Lampiri in the west to the city Diakopto in the east, and is oriented along the WNW-ESE direction (Figure 1). The coastal zone comprises a series of seven coastal alluvial fans of Late Holocene age, formed by seven torrential streams that drain the mountainous northern Peloponnese (Figure 1a). The drainage basins of these streams range in area from $7.8 \mathrm{~km}^{2}$ (Lagadi stream catchment) to $330.5 \mathrm{~km}^{2}$ (Selinous River catchment) (Rozos et al., 2011). The coast along the fans' aprons consists of unconsolidated alluvial deposits (mainly pebbles, cobbles, gravels and coarse sand).

The Gulf of Corinth (or the Corinth Rift) is one of the most active neotectonic features of the Eastern Mediterranean. It is a 'back arc' elongated graben, formed by normal faulting associated with an approximately N-S crustal extension (Armijo et al., 1996). The southern side of the Gulf, where the coast of the study area is located, is affected by the North dipping active normal faults of Aigion, and Eliki (Figure 1). The fan deltas' coastline lies on the hanging walls of the faults. The Gulf is a bathymetrically restricted marine embayment, with a nearly $105 \mathrm{~km}$ longitudinal axis lying in the E-W direction (Figure 1b). The embayment has an average width of approximately $320 \mathrm{~km}$, whilst water depths are in excess of $900 \mathrm{~m}$ in the central section. To the west, the gulf is linked with the Gulf of Patras through the narrow and shallow silled Rion Straits $(2 \mathrm{~km}$ wide and $65 \mathrm{~m}$ deep), which, in turn, is connected to the open Ionian Sea. The Corinth Canal (an artificially 
dredged channel, $8 \mathrm{~m}$ deep and $21 \mathrm{~m}$ wide) links the Gulf of Corinth with the Saronikos Gulf and the western Aegean Sea, to the east.

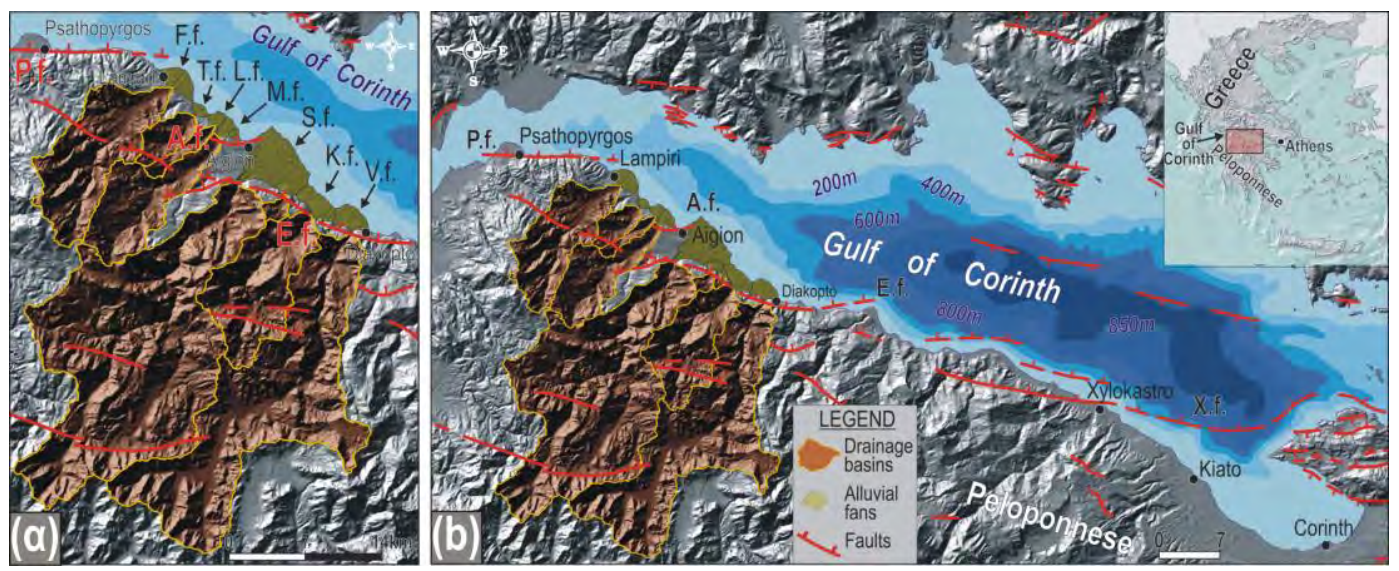

Figure 1 - (a) Location of the study area coastline. The map shows the fan deltas and their co rresponding catchments. The main active normal faults that affect the coastline of the study area are also depicted. (F.f.: Finix fan, T.f.: Tholopotamo fan, L.f.: Lagadi fan, M.f.: Meganit as fan, S.f.: Selinous fan, K.f.: Kerinitis fan, V.f. Vouraikos fan, P.f.: Psathopyrgos fault, A.f.: Aigion fault, E.f.: Eliki fault, X.f.: Xylokastro fault). (b) Subaqueous morphology of the Gulf of Corinth.

The submarine bathymetry of the Gulf of Corinth consists of the continental shelf, the continental slope, the continental rise, and the abyssal plain (Heezen et al., 1966). The southern continental shelf is narrow $(<1 \mathrm{~km})$ and relatively steep $\left(4-8^{\circ}\right)$, with the shelf break occurring at a water depth of approximately $100 \mathrm{~m}$. In contrast, the northern continental shelf slopes gently $\left(1-2^{\circ}\right)$ and extends into the central part of the gulf into water depths of approximately $200 \mathrm{~m}$. The southern slope is narrow $(1.5-2.5 \mathrm{~km})$ and steep $\left(14-18^{\circ}\right)$, whereas the northern slope varies at between 3 and $7 \mathrm{~km}$ in width with a gradient of $5-7^{\circ}$ (Poulos et al., 1996)]. In the north, the continental rise is narrower $(1-2.5 \mathrm{~km})$ and steeper $\left(2-5^{\circ}\right)$ than in the south, where the width ranges between 1 and $5.5 \mathrm{~km}$ and the slope gradients are $1-3^{\circ}$. The southern characteristics are the result of coalescing submarine fans, which extend offshore from the steep southern continental slope to the abyssal plain. Finally, the abyssal plain occupies the middle section of the central basin at water depths $>800 \mathrm{~m}$. The plain is essentially a flat area with gradients of $<0.5^{\circ}$.

The Gulf can be characterized as a microtidal environment with an average mean tidal range of $0.15 \mathrm{~m}$ (Bariagin, 1972; Tsimplis, 1994). The surface water circulation is dominated by the funneling of both wind and water through the narrow Rion Straights and the adjacent western Gulf, where mean surface current velocities can exceed $100 \mathrm{~cm} / \mathrm{s}$ (Piper et al., 1990). The funneling also results in a highly bi-modal distribution of predominant wind directions either from the $\mathrm{E}$ or the WSW. Data for the University of Patras (Piper et al., 1982) suggest the easterly winds are both stronger and more persistent. The fetch from the $\mathrm{E}$ is much greater than from the SSW, since the Rion Straits minimize the passage of waves from the Gulf of Patras. Wave climate is primarily wind driven with offshore mean significant wave heights average heights $<0.3 \mathrm{~m}$ according to the output of the wave model (POSEIDON program) (Soukisian et al., 2007; Tsimplis, 1994), which have been calibrated with the use of offshore field measurements (Figure 2).

The general climatic conditions of the study area are typical of the temperate Mediterranean. The mean annual precipitation ranges from $800 \mathrm{~mm}$ near the coastline to more than $1,200 \mathrm{~mm}$ in the southernmost highlands. Rain is unevenly distributed between the cold and the hot period of the year, with most falling during the winter months. The mean annual temperature fluctuates between 15 and $17^{\circ} \mathrm{C}$. 


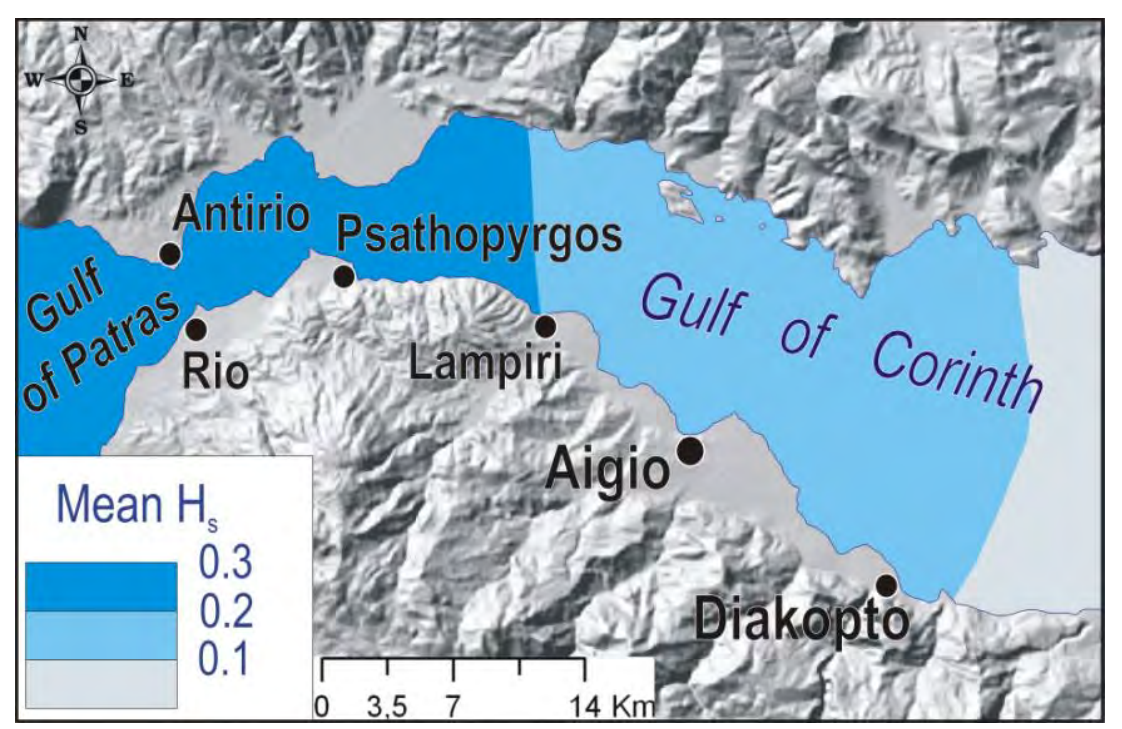

Figure 2 - Map of the mean significant wave height for the Gulf of Corinth. The map is modi fied from the Wave and Wind Atlas of the Hellenic Seas (Soukisian et al., 2007), which is bas ed on offshore measurements taken between 1999 and 2007 (POSEIDON program). The enti re coast of the study area is affected by waves with mean significant heights lower than $0.2 \mathrm{~m}$.

\section{Materials and Methods}

Shoreline erosion or accretion rates were derived using remote sensing data and utilizing Geographic Information System (GIS) techniques. Recent shoreline changes along the aprons of the seven fan deltas have been calculated from three series of orthorectified aerial photographs taken in 1945, 1996, and 2009. Detailed aerial photos of 1945 and 2008, at the scale of 1:1,000, were obtained from the Hellenic Cadastre (Ktimatologio S.A.) whereas 1996 aerial photos, at the scale of 1:33,000, were provided by the Greek Ministry of Rural Development and Food. For the purposes of this study a GIS spatial data base derived from detailed (at the scale of 1:5,000) topographic diagrams of the Hellenic Millitary Geographical Service, and the afore mentioned geometrically corrected aerial photographs was designed, organized and implemented using ESRI's ArcGIS9.3 software aiming at the creation of a number of thematic and synthetic layers and maps in a common projection system (Hellenic Geodetic Reference System 1987 HGRS'87). The digitizing of the shoreline as well as all measurements and calculations of coastal displacement rates for the two time periods were processed using GIS functions.

Aerial photographs were matched and a mosaic image of the study area was created for each date. The photomosaics of these aerial photos were manipulated within the GIS environment to digitize the shorelines of 1945, 1996, and 2008. The shoreline was defined as the observable land-sea interface at the time of photography. The thematic layers (in vector format) of the 1945, 1996, and 2008 shorelines were overlaid, and with the use of GIS-based distance analysis functions, the final shoreline change maps for the time periods of 1945-1996 and 1996-2009 were obtained with estimated accretion and erosion rates. For all analyses the coast of the study area was sectioned into seven analysis regions (Figures 3,4) each of which corresponds to an individual fan delta. Using the 1945 digitized shoreline, 628 measurement sites were created every 50m using an automated procedure. Coastal retreat or progradation was calculated for the interval between the dates of the imagery by measuring the distance separating the two shorelines (in vector format) perpendicular to the older shoreline. These distances were then divided by the number of years to provide average annual coastal retreat or accretion rates. 


\section{Results and Discussion}

For the presentation of the recent shoreline changes the study area is divided into seven sections. Each section corresponds to a fan delta. Coastline shifting rates were compiled for two periods: 1945-1996 and 1945-2008. Table 1 includes the regional results of the shoreline change analyses as well as the maximum accretion and erosion rates for each fan delta respectively. Horizontal shoreline changes of the study area for the 1945-1996 period varied from $-124 \mathrm{~m}$ to $+158 \mathrm{~m}$ (negative changes are erosional) and for the $1945-2008$ period from $-130 \mathrm{~m}$ to $+195 \mathrm{~m}$.

Table 1 - Maximum coastline change (retreat or accretion) rates estimated along the fan deltas' aprons for the periods 1945-1996 and 1945-2008. The table includes also the length of the eroded and prograted coastline for each fan delta.

\begin{tabular}{|c|c|c|c|c|c|c|c|}
\hline \multicolumn{8}{|c|}{ 1945-2008 } \\
\hline \multirow[t]{2}{*}{ Fan delta } & \multirow{2}{*}{$\begin{array}{c}\text { Shoreline } \\
\text { Length } \\
(\mathbf{k m})\end{array}$} & \multicolumn{3}{|c|}{ Retreat } & \multicolumn{3}{|c|}{ Accretion } \\
\hline & & km & $\%$ & $\begin{array}{l}\text { Maximum } \\
\text { rate }\end{array}$ & km & $\%$ & $\begin{array}{l}\text { Maximum } \\
\text { rate }\end{array}$ \\
\hline Finix & 5.75 & 5.50 & 95.7 & -2.06 & 0.15 & 2.6 & +0.10 \\
\hline Tholopotamos & 1.95 & 1.70 & 87.2 & -0.53 & 0.20 & 10.3 & +0.43 \\
\hline Lagadi & 1.90 & 1.70 & 89.5 & -0.41 & 0.20 & 10.5 & +0.20 \\
\hline Meganitas & 3.65 & 2.15 & 58.9 & -0.49 & 1.45 & 39.7 & +3.09 \\
\hline Selinous & 9.75 & 4.95 & 50.8 & -1.00 & 4.50 & 46.2 & +2.32 \\
\hline Kerinitis & 3.30 & 2.50 & 75.8 & -0.96 & 0.80 & 24.2 & +1.60 \\
\hline Vouraikos & 5.10 & 2.75 & 53.9 & -0.40 & 2.20 & 43.1 & +2.29 \\
\hline \multicolumn{8}{|c|}{ 1945-1996 } \\
\hline \multirow[t]{2}{*}{ Fan delta } & \multirow{2}{*}{$\begin{array}{c}\text { Shoreline } \\
\text { Length [m] }\end{array}$} & \multicolumn{3}{|c|}{ Retreat } & \multicolumn{3}{|c|}{ Accretion } \\
\hline & & km & $\%$ & $\begin{array}{l}\text { Maximum } \\
\text { rate }\end{array}$ & km & $\%$ & $\begin{array}{l}\text { Maximum } \\
\text { rate }\end{array}$ \\
\hline Finix & 5.75 & 4.90 & 85.2 & -2.44 & 0.65 & 11.3 & +0.22 \\
\hline Tholopotamos & 1.95 & 1.55 & 79.5 & -0.59 & 0.35 & 17.9 & +0.49 \\
\hline Lagadi & 1.90 & 1.00 & 52.6 & -0.49 & 0.85 & 44.7 & +0.53 \\
\hline Meganitas & 3.65 & 2.20 & 60.3 & -0.36 & 1.40 & 38.4 & +1.18 \\
\hline Selinous & 9.75 & 3.95 & 40.5 & -1.19 & 4.80 & 49.2 & +3.00 \\
\hline Kerinitis & 3.30 & 2.15 & 65.2 & -1.22 & 0.95 & 28.8 & +2.08 \\
\hline Vouraikos & 5.10 & 2.40 & 47.1 & -0.41 & 2.35 & 46.1 & +3.10 \\
\hline
\end{tabular}

A total length of $21.25 \mathrm{~km}$ which corresponds to the $67.7 \%$ of the total shoreline length of the seven fan deltas is being eroded with mean retreat rates varying between -0.10 and $-2.06 \mathrm{~m} / \mathrm{yr}$. Almost the entire Finix fan delta coastline (95.7\% of its total length) is retreating with mean longterm erosion rates reaching $-2.06 \mathrm{~m} / \mathrm{yr}$ for the period between 1945 and 2008 . Additionally, $89.5 \%$ and $87.2 \%$ of the Tholopotamos and Lagadi fan deltas shoreline is erosional, retreating at a maximum mean rate of -0.53 and $-0.43 \mathrm{~m} / \mathrm{yr}$ between 1945 and 2008 . The results indicate that erosion is the main process for fan deltas with small areas whereas an extensive segment of the large deltas such as those of Selinous and Vouraikos is prograding at rates reaching up to +2.32 $\mathrm{m} / \mathrm{yr}$ and +2.29 . The most extensive fan deltas have resulted from drainage networks which drain 


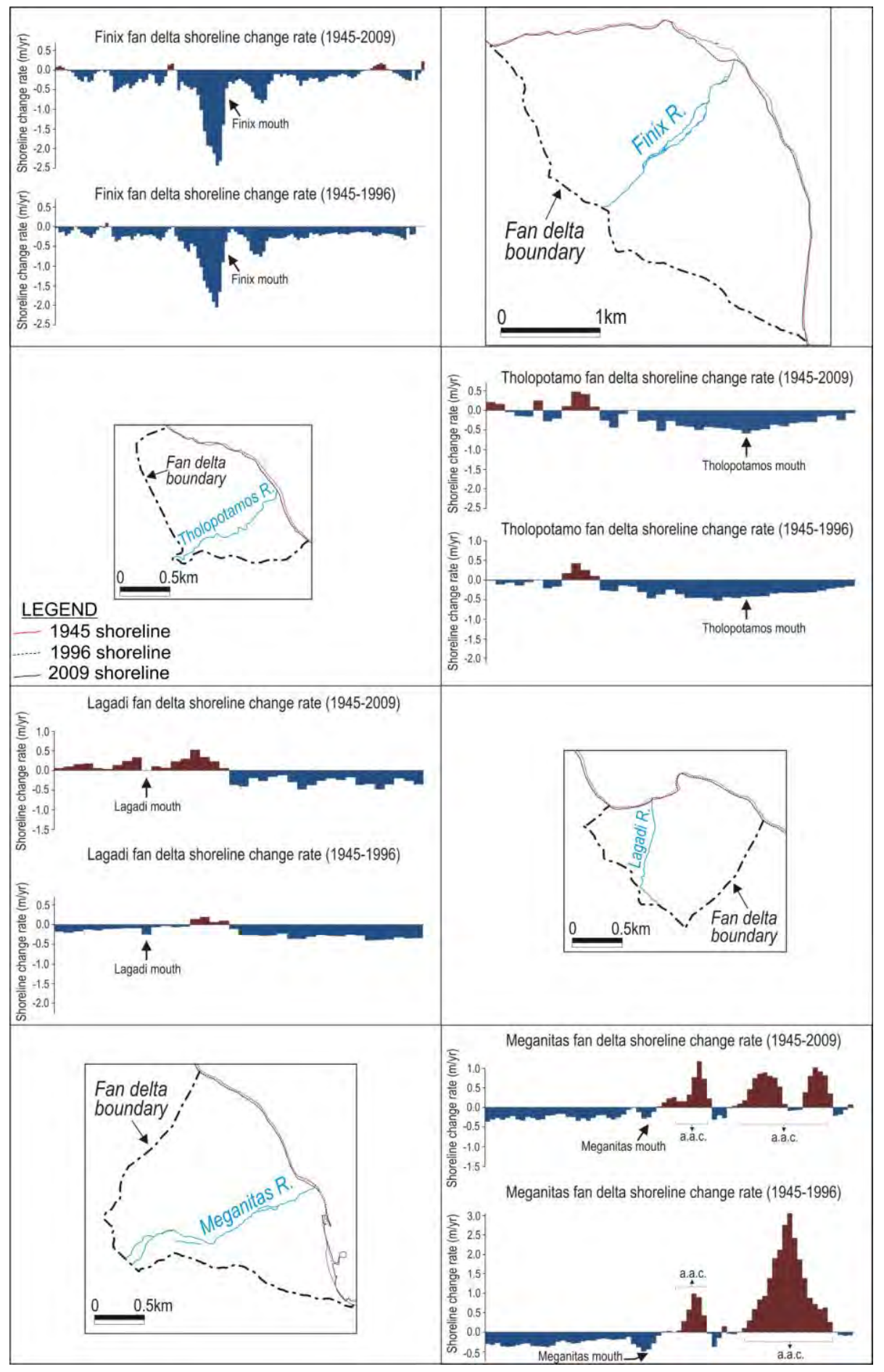

Figure 3 - Shoreline change rates for the fan deltas of Finix, Tholopotamo, Lagadi and Meganitas. Bar diagrams show mean shoreline change (retreat or progradation) rates for each $50 \mathrm{~m}$ segment along the fan delta coastline. Maps show the relative positions of the coastline along the apron of each one of the four fan deltas in 1945, 1996 and 2008 respectively (a.a.c.: artificially armored coast). 


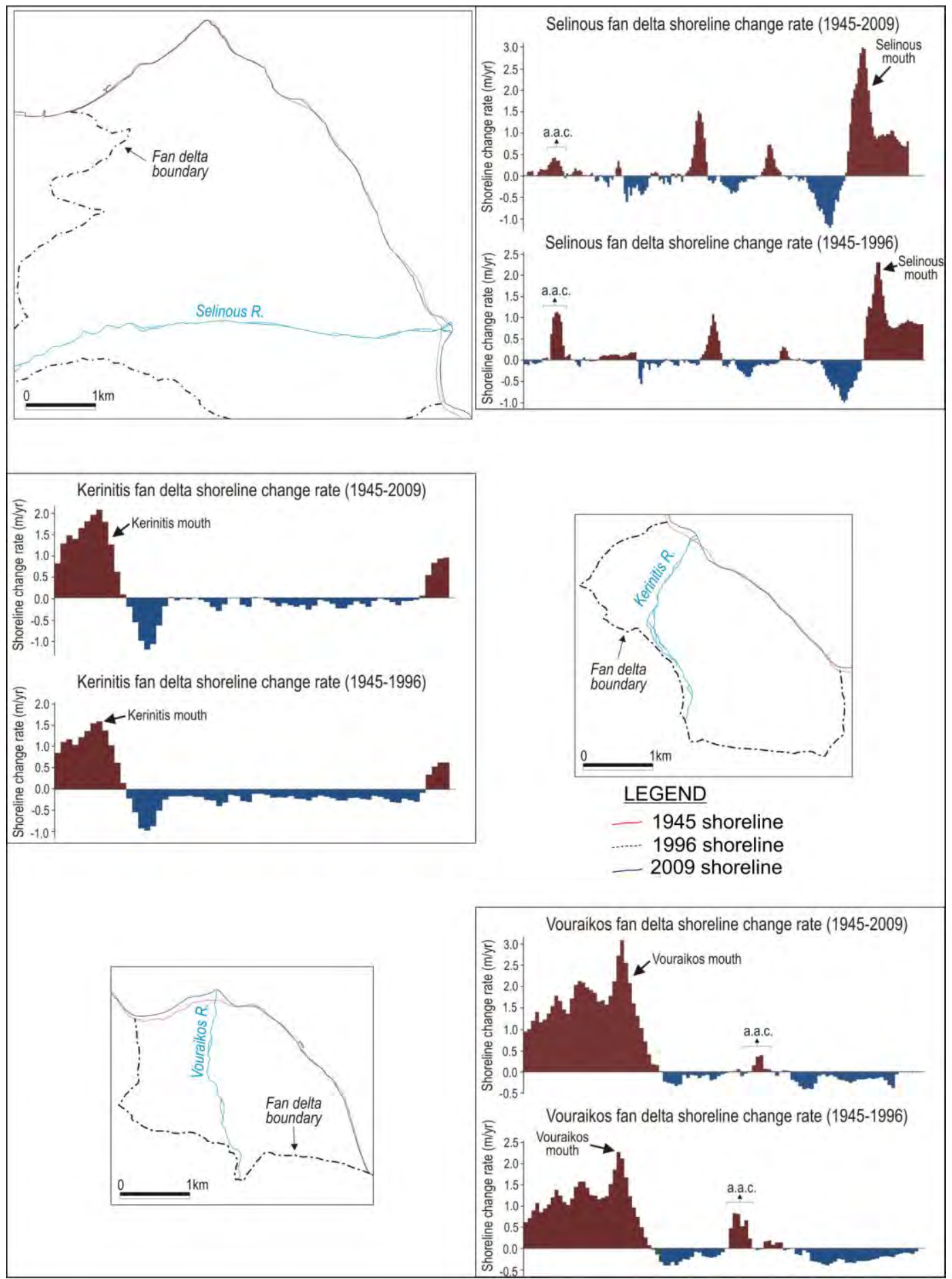

Figure 4 - Shoreline change rates for the fan deltas of Selinous, Kerinitis and Vouraikos. Bar diagrams show mean shoreline change (retreat or progradation) rates for each $50 \mathrm{~m}$ segment along the fan delta coastline. Maps show the relative positions of the coastline along the apron of each one of the three fan deltas in 1945, 1996 and 2008 respectively(a.a.c.: artificially armored coast). 
extensive mountainous areas composed mainly of highly erodible geological formations. For instance $57.8 \%$ of Vouraikos River drainage basin and 52,0\% of Selinous River catchment consist of easily erodible geological formations (Karymbalis \& Gaki-Papanastassiou, 2011). Seaward progradation occurred mainly at the locations around the active mouths of these major rivers due to increased fluvial supply. Thus high rates of accretion can be attributed to high influxes of sediment from river systems of perennial flow especially during the rainy period of the year.

High mean progradation rates reaching $3.09 \mathrm{~m} / \mathrm{yr}$ are also observed along artificially armored segments of the shorelines at the fans of Meganitas, Selinous and Vouraikos streams. consequently the long term accretional signal is likely related not only to large fluxes of sediment from the larger river systems but also to artificially armored segments of the coastline.

The spatial distribution of coastal retreat rates is presented in Figures 3 and 4 . The maps of the Figures show that the greatest erosion rates correspond to shorelines with NW-SE orientation that are exposed to easterly winds which according to Piper et al., (1990) are both stronger and more persistent. The fetch from the $\mathrm{E}$ is much greater than from the SSW. Given the fact that wave climate of the Gulf is primarily wind driven (Poulos et al., 1996) wave action must be the main cause of erosion.

The coastline of some of the fans of the study area has suffered earthquake induced instability events. The main mechanism responsible for the observed mass movements include the frequent seismic activity in the region, the high sedimentation rates of the numerous river mouths, heavy rainfall and high seas, and the steep slopes (Hassiotis et al., 2002). Historical observations that give evidence of earthquake induced nearshore sediment failures are: the destruction of Eliki (Helice) and the surrounding area in 373 BC after a severe seismic shock of an estimated magnitude 7.3 R (Papazachos and Papazachou, 1989) and the submergence of coastal strips between Meganitas and Vouraikos rivers in the southern Corinth Gulf in 1817 and 1861 due to the 6.5 R and 6.7 R earthquakes, respectively (Hassiotis et al., 2002). It is estimated that the entire alluvial plain of the fan deltas of Kerinitis and Vouraikos Rivers, which lay at the hanging wall of the eastern segment of the Eliki fault, has subsided at a rate of $1.4 \mathrm{~mm} / \mathrm{yr}$ resulting in the burial of the Late Hellenistic-Roman occupation horizons under $3 \mathrm{~m}$ of fluvial sediments (Koukouvelas et al., 2001; Pavlides et al., 2004). Coastal failures, slumping, liquefaction, ground cracking and tectonic ground ruptures have also been certified during the last 40 years along the coast of the study area (Palyvos et al., 2005). The most affected by these secondary processes fans are those of Finix, Selinous and Meganitas. On June 15 1995, a locally destructive earthquake of Ms=6.2 R with a hypocenter of a depth of about $10 \mathrm{~km}$ occurred in the western Gulf of Corinth (Bernard et al., 1997), causing coastal sediment failures in the broader area of Aegion (Papatheodorou and Ferentinos, 1997). From the above mentioned it is obvious that erosion along segments of the Finix, Selinous, Meganitas and Vouraikos fan deltas coastline can be also attributed to both longterm subsidence and earthquake induced instability events.

\section{Conclusions}

In this analysis the assessment of shoreline changes for a part of the coast of the north Peloponnese using orthorectified aerial photos from 1945, 1996 and 2008 and utilizing GIS techniques is attempted. Data procedure in the analytical context of GIS provided data integration which includes a common geographical reference system (which was HGRS'87), common spatial and temporal coverage, and similar scale and quality of the data.

Today coastal erosion is the main dominant geomorphic process along a significant part (about $68 \%$ ) of the fan deltas coastline. Maximum mean coastal retreat rates for the period 1945-1996 range from $-0.36 \mathrm{~m} / \mathrm{yr}$ (Meganitas fan delta) to $-2.44 \mathrm{~m} / \mathrm{yr}$ (Finix fan delta) whereas for the 19452008 period calculated maximum erosion rates range between $-0.40 \mathrm{~m} / \mathrm{yr}$ (Vouraikos fan delta) and $-2.06 \mathrm{~m} / \mathrm{yr}$ (Finix fan delta). 
The spatial distribution of coastal erosion shows that retreat correspond to shoreline segments with the ENE exposures which is consistent with the fact that waves, which are driven by the easterly winds are both stronger and more persistent.

One additional reason for the coastal erosion of the fans of Finix, Meganitas, Selinous and Vouraikos seems to be instability events triggered by earthquakes. Coastal failures, slumping, liquefaction and ground cracking have been certified during the last 40 years for fans of the north Peloponnese while the coastline of some of these fan deltas has suffered severe earthquake induced submarine instability events.

Estimated maximum mean coastal accretion rates for the periods 1945-1996 range from +0.22 $\mathrm{m} / \mathrm{yr}$ (Finix fan delta) to $+3.00 \mathrm{~m} / \mathrm{yr}$ (Selinous fan delta) whereas for the $1945-2008$ period maximum progradation rates range between $+0.10 \mathrm{~m} / \mathrm{yr}$ (Finix fan delta) and $+3.09 \mathrm{~m} / \mathrm{yr}$ (Selinous fan delta). Overall rates of shoreline accretion are higher in extensive fan deltas like those of Vouraikos and Selinous Rivers as compared with smaller fans. Seaward progradation occurred mainly in the locations of the active mouth of these streams. This can be attributed mainly to the higher sediment supply since these rivers drain extensive mountainous areas of relatively easily erodible lithology. Additionally, high mean accretion rates were associated with sites of artificially armored coastlines. Thus high accretion rates are likely related to influxes of sediment from large river systems as well as to artificially armored segments of the shoreline.

\section{References}

Armijo R., Meyer B., King G., Rigo A. and Papanastassiou D. 1996. Quaternary evolution of the Corinth Rift and its implications for the Late Cenozoic evolution of the Aegean, Geophys $J$ Int $126,11-53$.

Bariagin M.A. 1972. Tides and tidal data for Greek harbours, Hydrographic Service, Athens (in Greek).

Bernard P., Briole P., Meyer B., Lyon-Caen H., Gomez J.M., Tiberi C., Berge C., Cattin R., Hatzfeld D., Lachet C., Lebrun B., Deschamps A., Courboulex F., Larroque C., Rigo A., Massonnet D., Papadimitriou P., Kassaras J., Diagourtas D., Makropoulos K., Veis G., Papazisi E., Mitsakaki C., Karakostas V., Papadimitriou E., Papanastassiou D., Chouliaras G. and Stavrakakis G. 1997. The Ms=6.2R June 151995 Aegion Earthquake (Greece): Evidence for low angle normal faulting in the Corinth rift, J. Seismol., 1, 131-150.

Esteves L.S., Williams A., Nock A. and Lympery G. 2009. Quantifying shoreline changes along the Sefton coast (UK) and the implications for research-informed coastal management, Journal of Coastal Research, Special Issue 56, 602-606.

Foteinis S., Papadopoulos C., Koutsogiannaki I. and Synolakis C. 2010. Coastal erosion and accret ion rates in Greece, Geophysical Research Abstracts, 12, EGU2010-7499.

Hassiotis T., Papatheodorou G., Bouckovalas G., Corbau C. and Ferentinos G. 2002. Earthquakeinduced coastal sediment instabilities in the western Gulf of Corinth, Greece, Marine Geology, 182, 319-335.

Heezen B.C., Ewing M. and Johnson G.L. 1966. The Gulf of Corinth floor, Deep Sea Research 13, $381-411$.

Karymbalis E. and Gaki-Papanastassiou K. 2011. Investigation of relationships between fan delta and drainage basin morphometric variables along the southwestern coast of Gulf of Corinth, Northern Peloponnesus, Greece, in: Efe, R., Cravins, G., Ozturk, M., and Atalay, I., eds., Natural Environment and Culture in the Mediterranean Region II, 87-106, Cambridge Scholars Publishing UK.

Koukouvelas I., Stamatopoulos L., Katsonopoulou D. and Pavlidis S. 2001. A palaeoseismological and geoarchaeological investigation of the Eliki fault, Gulf of Corinth, Greece, Journal of Structural Geology, 23, 531-543.

Maroukian H. and Karymbalis E. 2004. Geomorphic evolution of the fan delta of the Evinos river in western Greece and human impacts during the last 150 years, Z Geomorphol 48,201-217.

$\underline{\text { XLVII, No } 1 \text { - } 323}$ 
Palyvos N., Pantosti D., De Martini P.M., Lemeille F., Sorel D. and Pavlopoulos K. 2005. The Aigion-Neos Erineos coastal normal fault system (western Corinth Rift, Greece): Geomorphological signature, recent earthquake history, and evolution, Journal of Geophysical Research, 110, B09302.

Papadopoulos C. 2009. Comprehensive assessment of coastal erosion in the regions of north A mvrakikos Gulf, Acheloos delta, Nestos delta, Kos, Limnos, and Kitros, Diploma Thesis, T echnical University of Crete, Chanea, Greece.

Papatheodorou G. and Ferentinos G. 1997. Submarine and coastal sediment failure triggered by the 1995, Ms=6.1R Aegion earthquake, Gulf of Corinth, Greece, Marine Geology, 137, 287-304.

Papazachos B. and Papazachou K. 1989. The seismicity of Greece, Ziti Publ., Thessaloniki.

Pavlides S.B., Koukouvelas I.K., Kokkalas S., Stamatopoulos L., Keramydas D. and Tsodoulos I. 2004. Late Holocene evolution of the East Eliki fault, Gulf of Corinth (Central Greece), Quaternary International, 115-116, 139-154.

Piper D.J.W., Kontopoulos N., Anagnostou C., Chronis G. and Panagos A.G. 1990. Modern fandeltas in the western Gulf of Corinth, Greece, Geo-Marine Letters, 10, 5-12.

Piper D.J.W., Panagos A.G., Kontopoulos N. and Spiliotopoulou M. 1982. Coastal Processes and morphology, Gulfs of Patras, Greece, Z Geomorphol, 26, 365-374.

Piper D.J.W., Stamatopoulos L., Poulimenos G., Doutsos T. and Kontopoulos N. 1990. Quaternary history of the Gulfs of Patras and Corinth, Greece, Z Geomorphol, 34, 451-458.

Poulos S.E., Collins M.B., Pattiaratchi A., Cramp A., Gull W., Tsimplis M. and Papatheodorou G. 1996, Oceanography and sedimentation in the semi-enclosed, deep-water Gulf of Corinth (Greece), Marine Geology, 134, 213-235.

Rozos D., Bathrellos G.D. and Skillodimou H.D. 2011. Comparison of the implementation of rock engineering system and analytic hierarchy process methods, upon landslide susceptibility mapping, using GIS: a case study from the Eastern Achaia Country of Peloponnesus, Greec e, Environ Earth Sci, 63, 49-63.

Soukisian T., Hatzinaki M., Korres G., Papadopoulos A., Kallos G. and Anadranistakis E. 2007, Wave and wind Atlas of the Hellenic Seas, Hellenic Centre for Marine Research Publ.

Tsimplis M.N. 1994. Tidal oscillations in the Aegean and Ionian Seas, Estuarine, Coastal and Shel f Science, 39, 201-208. 